\title{
PENGEMBANGAN MEDIA RODA PUTAR PADA MATA PELAJARAN IPS BERBASIS HOTS KERAGAMAN SUKU DAN BUDAYA KELAS 4 DI MI PSM PADANGAN KABUPATEN TULUNGAGUNG
}

\author{
Nuril Nuzulia ${ }^{1}$, Elok Khoirul Muna Mabni Zain ${ }^{2}$ \\ ${ }^{1,2}$ Universitas Islam Negeri Maulana Malik Ibrahim Malang \\ 1nuril.nuzulia@uin-malang.ac.id, ${ }^{2}$ elokkhoirulmuna@gmail.com
}

\begin{abstract}
Lack of learning media that can train higher order thinking skills is one of the causes of students' low creative thinking skills. So there is a need for the development of learning media that can see high-order thinking skills. The objectives of this research and development are to: (1) explain the process of composing the media for the media on the HOTS-based material of ethnic and cultural diversity, (2) to explain the attractiveness of using rotary wheel media in the Cultural diversity in my country based on HOTS, (3) explains the effectiveness of using rotary wheel media on HOTS-based ethnic and cultural diversity material. The research method used is the research and development method by adapting the Borg \& Gall development model. Data collection techniques used were observation, interviews, questionnaires, and tests. The research and development subjects were the fourth grade students of MI PSM Padangan Ngantru Tulungagung. The results of research conducted by researchers in the development of a media wheel with material of ethnic and cultural diversity show that (1) this rotary wheel media obtained a validity percentage of $86 \%$ from material experts, $86 \%$ from media design experts, and 94\% from learning experts, (2) ) this rotary wheel media has an attractiveness rate of $87.1 \%$, (3) the results of the post-test scores that have been carried out show that there is a significant increase compared to the results of the pre-test, namely with a difference in the average value of $36-t$ indicates that $t$ count $>t$ table, meaning that Ha is accepted Ho is rejected. It is obtained tcount $=3.897$ and ttable $=1.94$. So that there are differences in students before and after using the diversity wheel media. So it can be concluded that HOTS-based rotating wheel media can improve learning outcomes.

Keywords: development, rotating wheel media, HOTS (Higher Order Thinking Skills), Cultural diversity in my country, learning outcomes
\end{abstract}

\begin{abstract}
Abstrak
Kurangnya media pembelajaran yang dapat melatih kemampuan berpikir tingkat tinggi merupakan salah satu penyebab rendahnya kemampuan berpikir kreatif siswa. Maka perlu adanya pengembangan media pembelajaran yang dapat melihat kemampuan berpikir tingkat tinggi.Tujuan penelitian dan pengembangan ini adalah untuk: (1) menjelaskan proses penyusunan media roda putar materi keragaman suku dan budaya berbasis HOTS, (2) menjelaskan kemenarikan penggunaan media roda putar pada materi keragaman budaya di negeriku berbasis HOTS, (3) menjelaskan efektifitas penggunaan media roda putar pada materi keragaman suku dan budaya berbasis HOTS.Metode penelitian yang digunakan adalah metode penelitian dan pengembangan dengan mengadaptasi model pengembangan Borg \& Gall. Teknik pengumpulan data yang digunakan adalah observasi, wawancara, angket, dan tes. Subjek penelitian dan pengembangan ini adalah siswa kelas IV MI PSM Padangan Ngantru Tulungagung. Hasil penelitian yang dilakukan oleh peneliti dalam pengembangan media roda putar materi keragaman suku dan budaya bahwa (1) media roda putar ini mendapatkan prosentase kevalidan sebesar $86 \%$ dari ahli materi, 86\% dari ahli desaim media, dan 94\% dari ahli pembelajaran, (2) media roda putar ini memiliki tingkat kemenarikan sebesar 87,1\%, (3) hasil nilai post test yang telah dilakukan menunjukkan bahwa adanya peningkatan yang signifikan dibandingkan hasil nilai pre test, yakni dengan ${ }^{\text {perbedaan }}$ rata-rata nilai sebesar 36. Hasil analisis dengan uji-t menunjukkan bahwa $t_{\text {hitung }}>$ $t_{\text {tabel, }}$ artinya $H_{a}$ diterima $H_{o}$ ditolak. Hal ini diperoleh $t_{\text {hitung }}=3,897$ dan $t_{\text {tabel }}=1,94$. Sehingga terdapat perbedaan pada siswa sebelum dan sesudah menggunakan media roda putar keragaman. Maka dapat disimpulkan bahwa media roda putar berbasis HOTS mampu meningkatkan hasil belajar.
\end{abstract}

Kata Kunci: pengembangan, media roda putar, kemampuan berpikir tingkat tinggi, keragaman suku dan budaya, hasil belajar 
Nuril Nuzulia, Wlok Khoirul Muna Mabni Zain : Pengembangan Media Putar Pada Mata Pelajaran IPS Berbasis HOTS Keragaman Suku dan Budaya Kelas 4 di MI PSM Padangan Kabupaten Tulungagung

\section{PENDAHULUAN}

Pendidikan merupakan usaha yang telah disusun, diatur, dan digunakan terus menerus hingga akhir hayat guna membimbing peserta didik sebagai manusia dewasa, paripurna, dan berbudaya. Membimbing harus mampu mengembangkan seluruh aspek potensi anak didik, meliputi: aspek kognitif berupa pengetahuan, aspek afektif berupa sikap, dan aspek psikomotorik berupa keterampilan. ${ }^{1}$

Termuat dalam Undang-Undang No. 20 Tahun 2003 pasal 3 tentang Sisdiknas pada Undang undang tersebut menyatakan tentang fungsi dan tujuan pendidikan nasional. ${ }^{2}$ Selain itu Q.S. Al-Imran ayat 104 juga menjelaskan tentang tujuan pendidikan sebagai berikut:

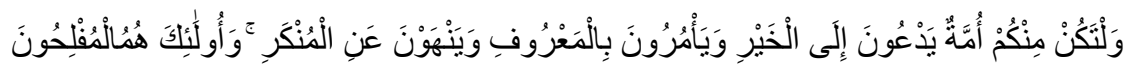

Artinya: "Dan hendaklah ada di antara kamu segolongan umat yang menyeru kepada kebajikan,menyuruh kepada yang ma'ruf dan mencegah dari yang munkar, merekalah orang-orang yang beruntung".

Mewujudkan tujuan pendidikan diatas, perlu menggunakan media pembelajaran dalam kegiatan belajar mengajar. Susilana dan Riyana dalam penelitiannya mengatakan media merupakan alat untuk memudahkan seorang guru agar proses pembelajaran berjalan efektif dan dapat mewujudkan tujuan pendidikan. ${ }^{3}$ Hal tersebut sesuai dengan seorang ahli Y.Miarso mengungkapkan bahwa media merupakan sesuatu yang dapat menstimulus dan memberi kemajuan siswa. ${ }^{4}$

Berdasarkan hasil pra penelitian di salah satu Madrasah Ibtidaiyah di Kabupaten Tulungagung pada tanggal 15 Oktober 2019. Berdasarkan hasil wawancara bersama guru mata pelajaran yang bernama Ni'matul Masruroh S.Pd mengungkapkan bahwa beliau kesulitan dalam mengambangkan media pembelajaran. Kesulitan tersebut membuat pelaksanaan pembelajaran materi keragaman suku dan budaya dalam mata pelajaran ilmu pengetahuan sosial kurang menarik dan monoton. Guru hanya menggunakan buku paket bergambar, lembar kerja siswa (LKS), dan masih menggunakan soal LOTS (Low Order Thinking Skills) sehingga peserta didik kurang tertarik. Permasalahan tersebut membuat nilai peserta didik kurang memuaskan ketika dilakukan evaluasi. Guru mata pelajaran menyarankan menggunakan media roda putar untuk mempermudah tersampaikannya materi pendidikan sosial.

Ilmu pendidikan sosial pada materi keragaman suku dan budaya dengan kompetensi dasar tersebut adalah mengidentifikasi berbagai raham budaya yang ada di Indonesia. Kompetensi dasar yang terdapat pada materi keragaman suku dan budaya kemudian dibuat soal. Soal yang dibuat berbasis HOTS (Higher Order

\footnotetext{
${ }^{1}$ Ahmad Susanto, Teori Belajar dan Pembelajaran di Sekolah Dasar, (Jakarta: Prenadamedia Group, 2015), hlm.

${ }^{2}$ Undang-Undang Republik Indonesia No. 20, Sisdiknas, (Bandung: Citra Umbara, 2003), hlm. 7

${ }^{3}$ Satriianawati, Media dan Sumber Belajar, (Yogyakarta: CV Budi Utama, 2018), hlm. 7

${ }^{4}$ Hujair Sanaky, Media pembelajaran, (Yogyakarta: Safiria Insania Press, 2009), hlm. 4
} 
Nuril Nuzulia, Wlok Khoirul Muna Mabni Zain : Pengembangan Media Putar Pada Mata Pelajaran IPS Berbasis HOTS Keragaman Suku dan Budaya Kelas 4 di MI PSM Padangan Kabupaten Tulungagung

Thinking Skills) yang disusun sesuai level kognitif menganalisis, mengevaluasi, dan mencipta. Kemampuan berfikir tingkat tinggi ini adalah sebuah kemampuan yang dibutuhkan pada abad 21. Kemampuan HOTS yang dikembangkan dari teori Blooms yang kemudian disempurnakan oleh Anderson dan Krathwohl.

Ilmu pendidikan sosial pada materi keragaman suku dan budaya dengan kompetensi dasar tersebut adalah mengidentifikasi berbagai raham budaya yang ada di Indonesia. Kompetensi dasar yang terdapat pada materi keragaman suku dan budaya kemudian dibuat soal. Soal yang dibuat berbasis HOTS (Higher Order Thinking Skills) yang disusun sesuai level kognitif menganalisis, mengevaluasi, dan mencipta. Kemampuan berfikir tingkat tinggi ini adalah sebuah kemampuan yang dibutuhkan pada abad 21. Kemampuan HOTS yang dikembangkan dari teori Blooms yang kemudian disempurnakan oleh Anderson dan Krathwohl.

Paparan diatas sejalan dengan penelitian Nurul Isnaini dan Rinawati. Nurul Isnaini menyatakan bahwa meningkatnya hasil belajar siswa melalui media roda putar pada mata pelajaran matematika materi gambar melalui media pembelajaran berbasis game roda putar di SD Purwantoro 4 Malang. ${ }^{5}$ Sedangkan, berdasarkan hasil penelitian yang dilakukan oleh rinawati bahwa melalui media roda putar dapat meningkatkan cara berhitung anak kelompok BTK Dharma Wanita Gandong Kecamatan Bandung Kabupaten Tulungagung. ${ }^{6}$ Penelitian terdahulu dapat diketahui bahwa media roda putar memiliki banyak kelayakan untuk dikembangkan. Media yang dikembangkan memiliki perbedaan dengan penelitian sebelumnya yaitu adanya soal dan gambar mengenai materi keragaman budaya negeriku.

Media roda putar dikembangkan untuk mempermudah siswa dalam hal memahami matei. Media ini memiliki keunggulan, sehingga peneliti memilih media ini. Keunggulannya antara lain: dapat memberikan stimulus kepada siswa untuk berpartisipasi aktif dan memerikan respon timbal balik secara langsung untuk pembelajaran yang efektif. Pembelajaran menggunakan media roda putar dikatakan efektif karena media digunakan sebagai alat bermain yang memiliki soal dan gambar. Oleh karena itu, media ini dapat menarik perhatian, merangsang minat belajar, dan motivasi belajar, serta eningkatkan hasil belajar siswa.

Kurikulum 2013 sebagai tuntutan di era globalisasi. Kurikulum 2013 diharapkan membentuk manusia indonesia yang inovatif, produktif, dan memiliki nilai-nilai positif, keterampilan, dan pengetahuan yang terintegrasi. Sistem yang digunakan dalam kurikulum 2013 menekankan kemampuan berpikir tingkat tinggi. Menurut Thomas dan Thorne mengatakan bahwa HOTS merupakan menghafalkan fakta, mengemukakan fakta, atau menerapkan peraturan, rumus, dan prosedur cara berpikir yang lebih tinggi dari semua itu. HOTS harus menerapkan dan melakukan sesuatu berdasarkan fakta. Seperti: materi yang disampaikan berkaitan dengan fakta, mengategorikan, memanipulasi, menempatkan pada konteks yang baru, dan dapat memecahkan masalah dengan membuat solusi baru. Sedangkan menurut Onosko \& Newman

\footnotetext{
${ }^{5}$ Nurul Isnaini, The development of learning media based on roda putar game on mathematic subjects of solid figure material for 5th grade of SDN Purwantoro 4 Malang, (Malang: UIN Malang, 2018), hlm. 7

${ }^{6}$ Rinawati, Meningkatkan Kemampuan Berhitung Melalui Media Roda Putar Pada Anak Kelompok B TK Dharma Wanita Gondang Kecamatan Bandung Kabupaten Tulungagung Tahun Pelajaran 2014/2015, (Kediri: Universitas Nusantara PGRI, 2015), hlm. 95
} 
Nuril Nuzulia, Wlok Khoirul Muna Mabni Zain : Pengembangan Media Putar Pada Mata Pelajaran IPS Berbasis HOTS Keragaman Suku dan Budaya Kelas 4 di MI PSM Padangan Kabupaten Tulungagung

dalam buku HOTS menyatakan bahwa HOTS merupakan non-algoritmik penggunaan pikiran yang digunakan untuk menghadapi tantangan baru. Berdasarkan uraian diatas media yang dikembangkan memiliki soal yang berbasis HOTS (Higher Order Thinking Skill) agar siswa mampu mengaplikasikan kemampuan berpikir yang dimiliki. Soal tersebut digunakan untuk mengetahui pengetahuan yang dimiliki siswa. Sehingga, guru dapat mengukur hasil belajar siswa sesuai dengan pengetahuan. ${ }^{7}$

Pelaksanaan penelitian ini dilakukan ketika dunia sedang waspada terhadap pandemi yang di sebut dengan corona virus (COVID-19) yang memilki tingkat penularan sangat cepat. Pemerintah Indonesia kemudian menerapkan lockdown atau karantina. Pada UU Republik Indonesia Nomor 6 tahun 2018 tentang kekarantinaan kesehatan ${ }^{8}$ sehingga, pembelajaran dilakukan secara online dengan sistem belajar dalam jaringan. Hal tersebut menjadi salah satu penyebab terbatasnya penelitian ini. Akan tetapi, masa pendemi bukan sebagai alasan untuk berhenti belajar, siswa harus tetap belajar dengan kelompok yang terbatas. Menggunakan media ini dapat menemani siswa untuk belajar dirumah, belajar sambil bermain akan membuat siswa tetap semangat dan tidak bosan.

MI PSM Padangan adalah Madrasah Ibtidaiyah yang memiliki akriditasi A dan berada di Kabupaten Tulungagung yang berasaskan Islam. Salah satu madrasah yang menekankan pada aspek kognitif dan spiritual yang berkembang sesuai dengan kurikulum yang berlaku. Sekolah ini berlokasi di desa sehingga, pengembangan media kurang diperhatikan dan perlu inovasi terbaru terhadap media yang mampu menarik siswa dalam pembelajaran.

Berdasarkan permasalahan diatas dan konsep teori pengembangan media, peneliti berfokus pada penelitian pengembangan yang berjudul "Pengembangan Media Roda Putar Pada Mata Pelajaran IPS Keragaman Suku dan Budaya Berbasis HOTS Untuk Meningkatkan Hasil Belajar Siswa Kelas 4 Di MI PSM Padangan Kabupaten Tulungagung”.

\section{METODE PENELITIAN}

Metode penelitian yang digunakan adalah penelitian pengembangan atau disebut Research and Development yang dilakukan di MI PSM Padangan Ngantru Kabupaten Tulungagung. Penelitian ini tertuju pada langkah-langkah yang dimiliki oleh Borg \& Gall. Menurut Borg \& Gall ada 10 langkah dalam penelitian pengembangan diantaranya disajikan pada gambar berikut:

\footnotetext{
${ }^{7}$ Arifin Nugroho, Higher Order Thinking Skills. (Jakarta: PT Gramedia, 2019), hlm. 16

${ }^{8}$ https://www.kemhan.go.id/itjen/wp-content/uploads/2018/10/uu6-2018pjl.pdf, pada tanggal 10 Agustus 2020, pukul 09.19
} 


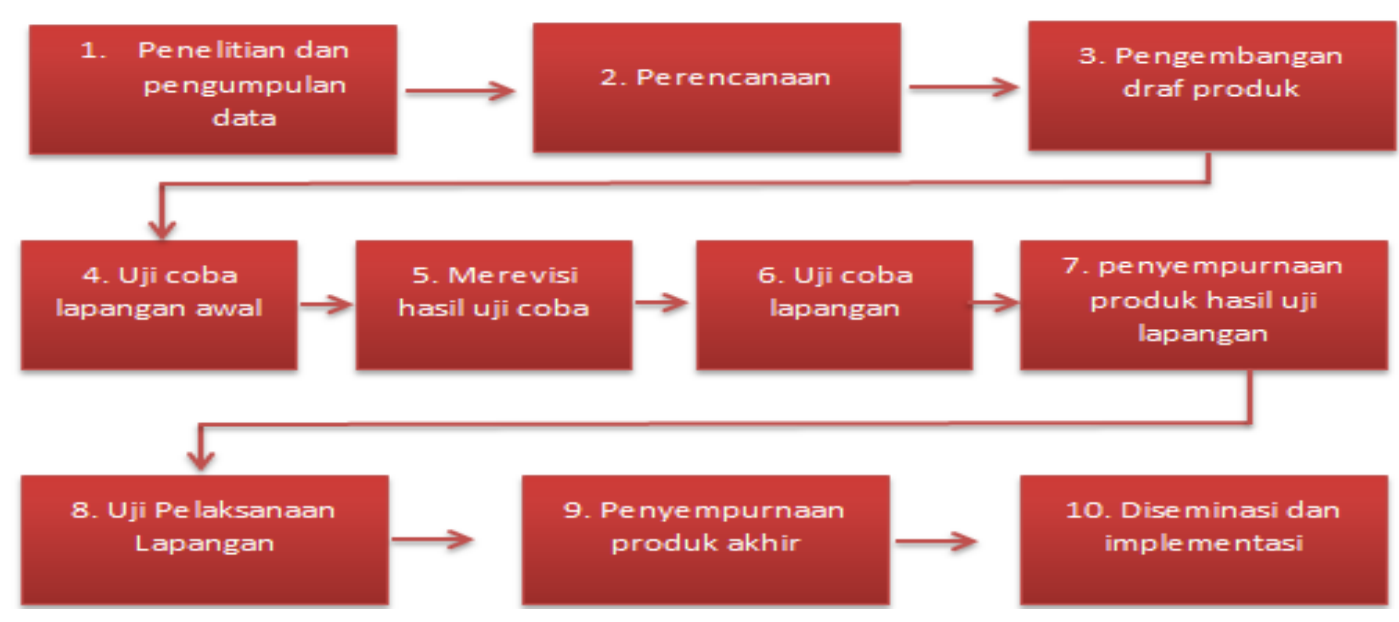

\section{Gambar 2.1 Langkah-Langkah Penelitian Pengembangan Borg \& Gall}

Berdasarkan langkah-langkah diatas, peneliti menggunakan tujuh langkah. Peneliti tidak sampai uji skala tingkat luas karena hanya dilakukan kepada peserta didik. Karena peneliti memiliki waktu dan biaya yang terbatas. Sedangkan, untuk langkah ke empat yang digunakan peneliti satu sekolah.

Pengujian produk yang dianggap sangat penting maka peneliti melakukan tahapan proses diantaranya melakukan uji coba produk pertama yang dilakukan pada ahli desain media dan ahli materi sehingga, dapat diketahui kesesuaian materi dengan media. Peneliti juga melakukan pengujian kepada guru mata pelajaran atau ahli praktisi. Uji coba terakhir kepada peserta didik yang diharapkan dapat menjawab rumusan masalah yang telah disusun.

\section{HASIL DAN PEMBAHASAN}

Hasil dari produk pengembangan ini disebut dengan media roda putar pada materi keragaman suku dan budaya berbasis HOTS untuk meningkatkan hasil belajar siswa kelas IV MI PSM Padangan.

\section{Identitas media}

Ciri-ciri : Produk pengembangan media roda putar berbahan dasar kayu yang dibentuk seperti roda. Bagian dalam dibagi menjadi 24 petak yang didalamnya akan ada katu soal yang telah disesuaikan dengan materi.

Sasaran : Siswa kelas IV MI PSM Padangan Ngantru Tulungagung

\section{Aspek Desain}


a. Papan permainan

Papan permaianan roda putar terdapat 24 petak yang terbagi menjadi 3 warna yaitu hijau, orange, dan putih. Pada petak tersebut terdapat gambar yang telah disesuaikan dengan materi keragaman suku dan budaya. Pada setiap petak terdapat kartu soal yang berwarna hijau, pink, dan kuning. Pada papan ini juga terdapat kartu cadangan yang berwarna putih. Pada papan permaianan bagian belakang terdapat tulisan sebagai berikut:

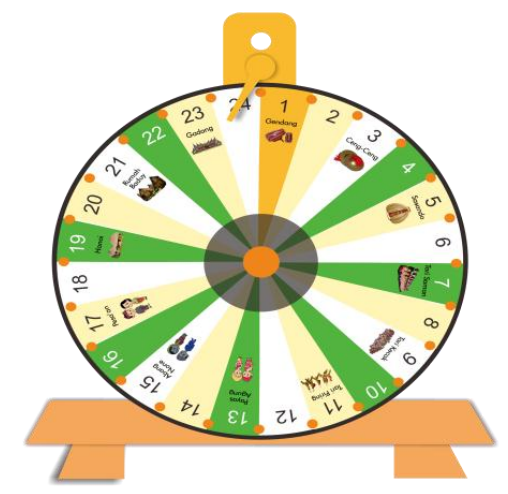

\section{Gambar 3.1 Media roda putar tampak depan}

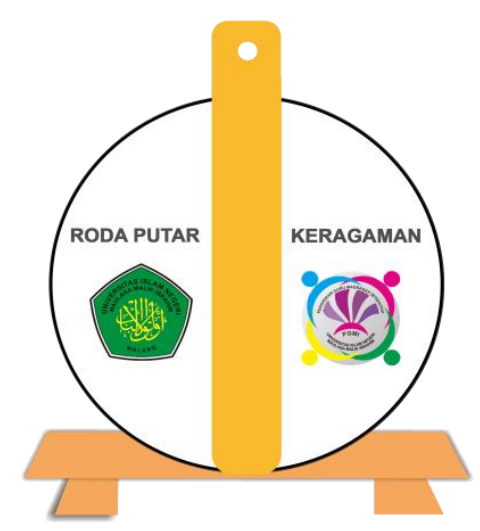

\section{Gambar 3.2 Media roda putar tampak belakang}

Pada gambar 3.1 merupakan media tampak depan yang terdapat terdiri dari nama (label keterangan) berbagai rumah adat daerah, pakaian adat, tarian adat, dan alat musik daerah. Masing-masing terdapat keunikannya yang disesuaikan dengan pokok bahasan yang dikembangkan. Pada gambar 3.2 merupakan media tampak belakang yang memiliki ldua logo. Pada bagian kanan mrupakan universitas islam negeri malang, sedangkan bagian kiri jurusan pendidikan guru madrasah ibtidaiyah dan bagian atas judul roda putar keragaman. 
Nuril Nuzulia, Wlok Khoirul Muna Mabni Zain : Pengembangan Media Putar Pada Mata Pelajaran IPS Berbasis HOTS Keragaman Suku dan Budaya Kelas 4 di MI PSM Padangan Kabupaten Tulungagung

b. Kartu pertanyaan budaya

Bagian kartu pertanyaan budaya dalam media ini berisi pertanyaan tentang bebagai rumah adat, pakaian adat, tarian adat, dan alat musik daerah.

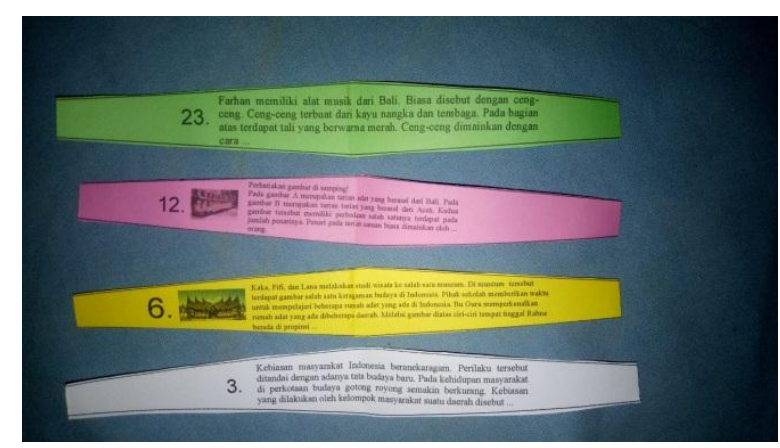

Gambar 3.3 kartu soal

c. Buku petunjuk penggunaan

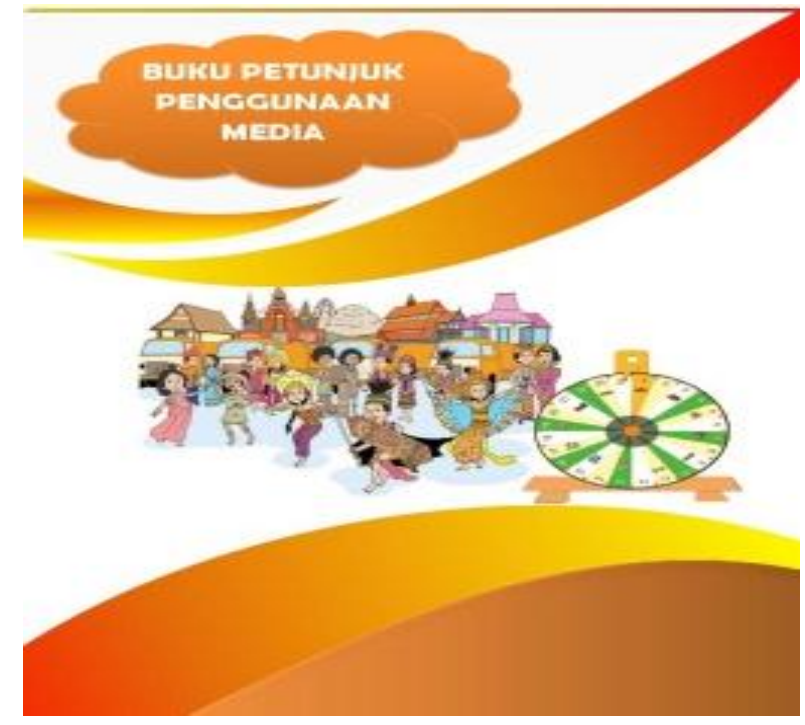

\section{Gambar 3.4 Halaman pertama buku}

Pada lembar pertama buku ini merupakan cover dan tertulis judul pada bagian atas buku petunjuk penggunaan. Desain pada buku ini menggunakan corel draw x7. Terdapat dua gambar yang menunjukkan bahwa buku ini merupakan buku keragaman dan menggunakan media roda putar. 
Nuril Nuzulia, Wlok Khoirul Muna Mabni Zain : Pengembangan Media Putar Pada Mata Pelajaran IPS Berbasis HOTS Keragaman Suku dan Budaya Kelas 4 di MI PSM Padangan Kabupaten Tulungagung

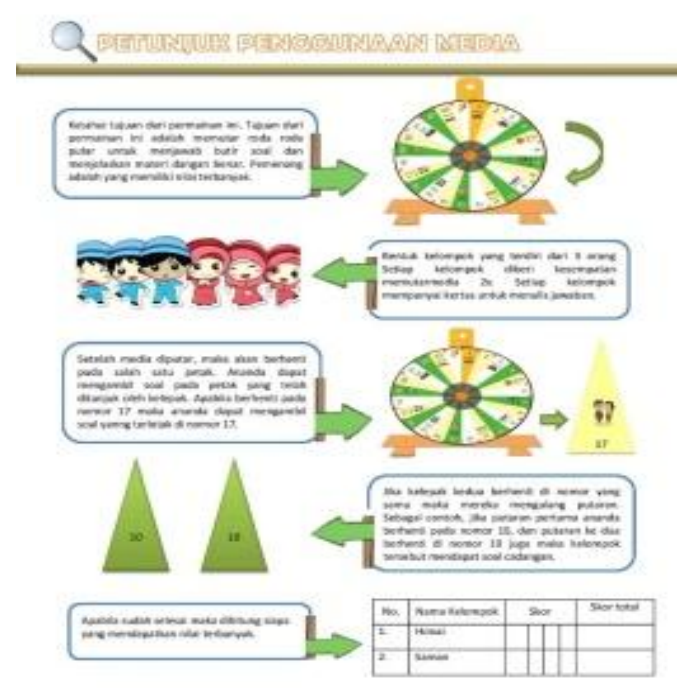

Gambar 3.5 Langkah-Langkah Penggunaan Media

Pada lembar kedua merupakan langkah-langkah penggunaan media yang telah di rinci dengan jelas. Langkah-langkahnya terdiri dari lima langkah yang harus dilakukan siswa untuk menggunakan media.

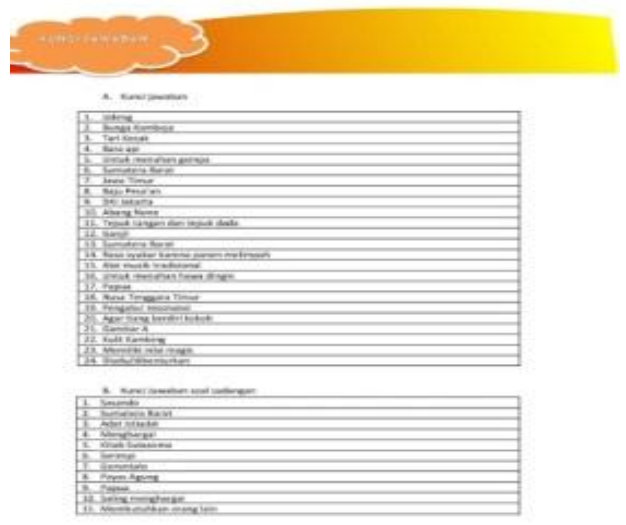

Gambar 3.6 Halaman ketiga

Pada lembar ketiga merupakan kunci jawaban dari soal yang yang telah disedikan pada media.

Terdapat 24 jawaban yang terdapat pada lembar ketiga ini. 
Nuril Nuzulia, Wlok Khoirul Muna Mabni Zain : Pengembangan Media Putar Pada Mata Pelajaran IPS Berbasis HOTS Keragaman Suku dan Budaya Kelas 4 di MI PSM Padangan Kabupaten Tulungagung

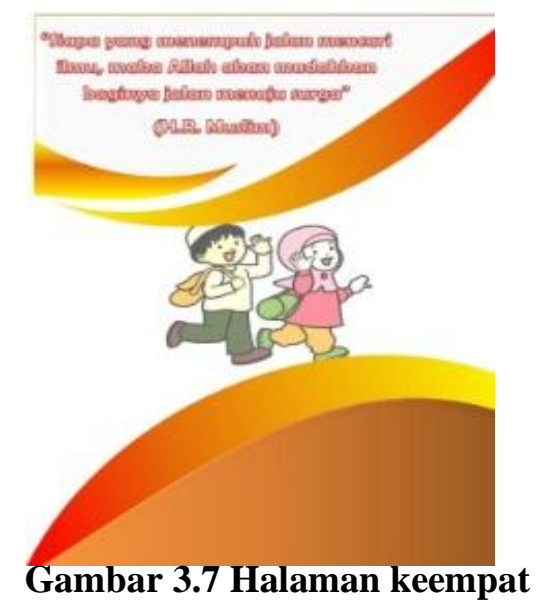

Pada lembar keempat merupakan cover buku bagian belakang terdapat kata-kata motivasi yang diharapkan dapat menjadi stimulus siswa untuk semangat dalam belajar.

Tahap selanjutnya adalah validasi kepada ahli materi yang dilakukan setelah penyusunan desain dan media.

Tabel 3.1

Hasil Kurva validasi ahli materi

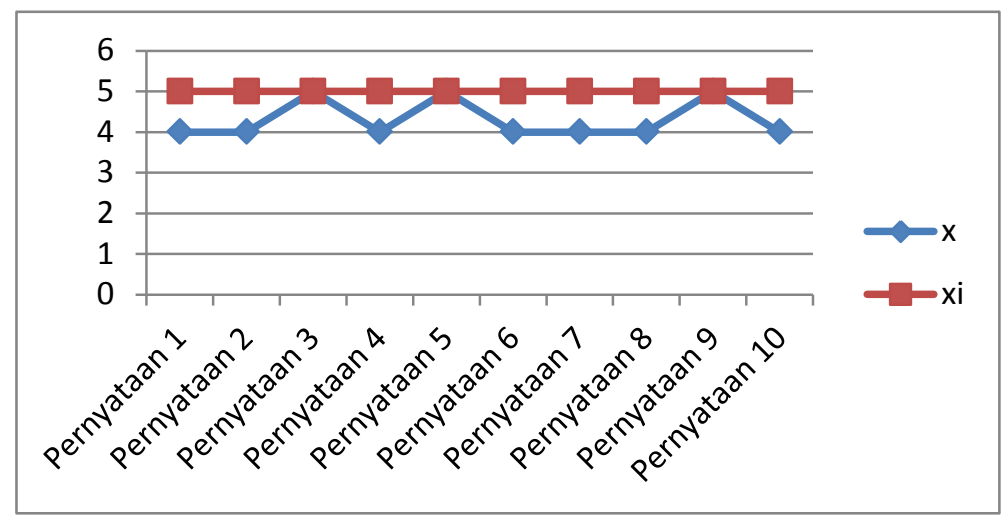

Data diatas dihitung dengan rumus seperti dibawah ini:

$$
\begin{aligned}
& P=\frac{\Sigma X}{\Sigma X i} \times 100 \% \\
& P=\frac{43}{50} \times 100 \%
\end{aligned}
$$


Nuril Nuzulia, Wlok Khoirul Muna Mabni Zain : Pengembangan Media Putar Pada Mata Pelajaran IPS Berbasis HOTS Keragaman Suku dan Budaya Kelas 4 di MI PSM Padangan Kabupaten Tulungagung

$$
=86 \%
$$

Hasil analisis yang didapatkan dari ahli materi diperoleh nilai kelayakan sebesar $86 \%$, prosentase ini menunjukkan bahwa media ini layak digunakan dengan kriteria valid. Data kualitatif sebagai berikut:

Tabel 3.2

Kritik dan saran ahli materi

\begin{tabular}{|l|l|}
\hline Nama validator & Kritik dan saran \\
\hline Galih Puji Mulyoto, M.Pd & $\begin{array}{l}\text { Semangat untuk melanjutkan } \\
\text { tahap selanjutnya. }\end{array}$ \\
\hline
\end{tabular}

Media roda putar divalidasi oleh ibu Vannisa Aviana Melinda, M.Pd pada bagian desain media. Berikut data yang diperoleh dari ahli desain media:

Tabel 3.3

Kurva Hasil Validasi Ahli Desain

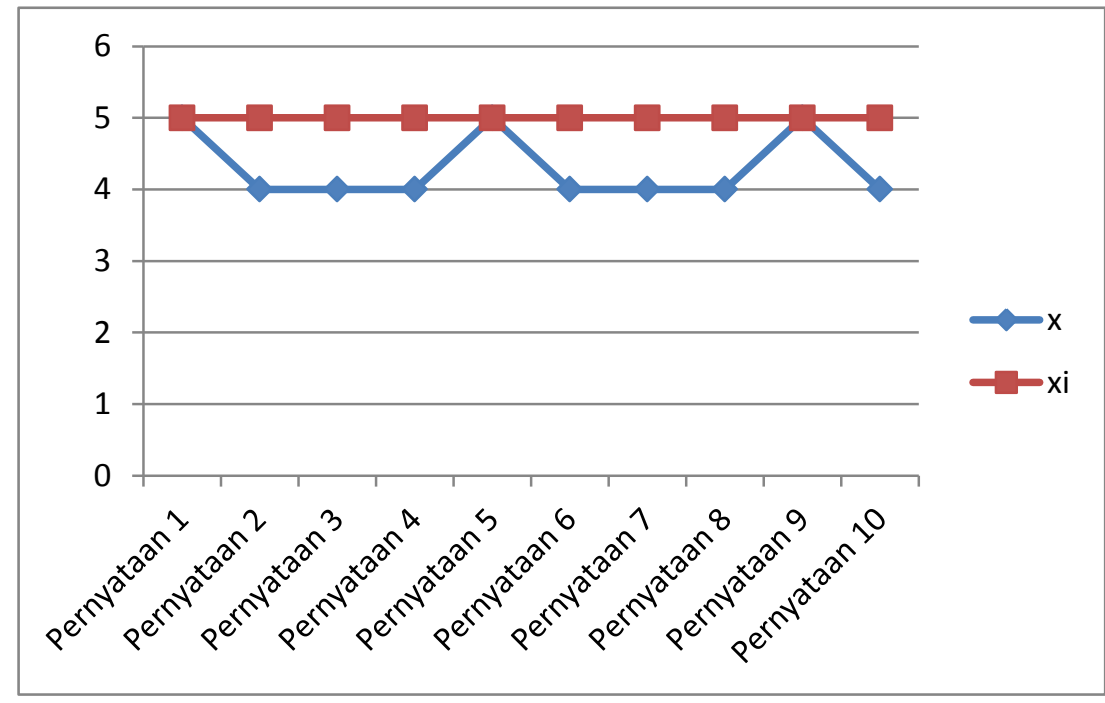

Data diatas dihitung dengan rumus seperti dibawah ini:

$$
\begin{aligned}
P & =\frac{\Sigma X}{\Sigma X i} \times 100 \% \\
P & =\frac{43}{50} \times 100 \% \\
& =86 \%
\end{aligned}
$$

Hasil analisis yang didapatkan dari ahli desain media diperoleh nilai kelayakan sebesar $86 \%$, prosentase ini menunjukkan bahwa media ini layak digunakan dengan kriteria valid. Data kualitatif sebagai berikut:

Tabel 3.4

Kritik Dan Saran Ahli Desain

\begin{tabular}{|l|l|}
\hline Nama Validator & Kritik dan saran \\
\hline
\end{tabular}


Nuril Nuzulia, Wlok Khoirul Muna Mabni Zain : Pengembangan Media Putar Pada Mata Pelajaran IPS Berbasis HOTS Keragaman Suku dan Budaya Kelas 4 di MI PSM Padangan Kabupaten Tulungagung

\begin{tabular}{|l|l|}
\hline Vannisa Aviana Melinda, M.Pd & $\begin{array}{l}\text { Warna pada papan permainan } \\
\text { diberi yang lebih terang merah } \\
\text { atau hijau }\end{array}$ \\
\hline
\end{tabular}

Guru mata pelajaran atau praktisi media roda putar ini adalah Ni'matul Masruroh, S.Pd. Data kuantitatif yang diperoleh sebagai berikut:

Tabel 3.5

Kurva Praktisi

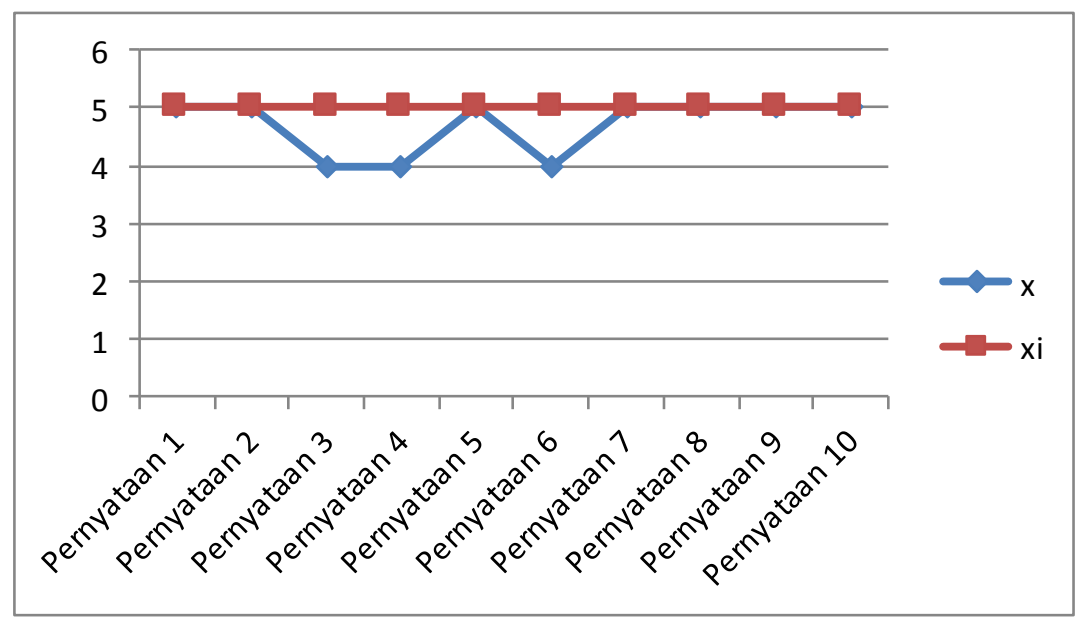

Data diatas dihitung dengan rumus seperti dibawah ini:

$$
\begin{aligned}
P & =\frac{\Sigma X}{\Sigma X i} \times 100 \% \\
P & =\frac{47}{50} \times 100 \% \\
& =94 \%
\end{aligned}
$$

Hasil analisis yang didapatkan dari praktisi diperoleh nilai kelayakan sebesar 94\%, prosentase ini menunjukkan bahwa media ini layak digunakan dengan kriteria valid. Data kualitatif sebagai berikut:

Tabel 3.6

Kritik Dan Saran Ahli Praktisi

\begin{tabular}{|c|lrr|}
\hline Praktisi & \multicolumn{2}{|c|}{ Kritik dan saran } \\
\hline Ni'matul Masruroh, S.Pd & Kelebihannya & menarik dan mampu \\
& memberikan & semangat & kepada \\
& siswa. & Kekurangannya \\
& membutuhkan & waktu & untuk \\
& mengenalkan & media & tersebut \\
& kepada siswa. & \\
\hline
\end{tabular}


Nuril Nuzulia, Wlok Khoirul Muna Mabni Zain : Pengembangan Media Putar Pada Mata Pelajaran IPS Berbasis HOTS Keragaman Suku dan Budaya Kelas 4 di MI PSM Padangan Kabupaten Tulungagung

Subjek dari uji kemenarikan adalah siswa kelas IV di MI PSM Padangan, berikut pemaparan data hasil uji coba:

Tabel 3.7

Kurva kemenarikan oleh siswa

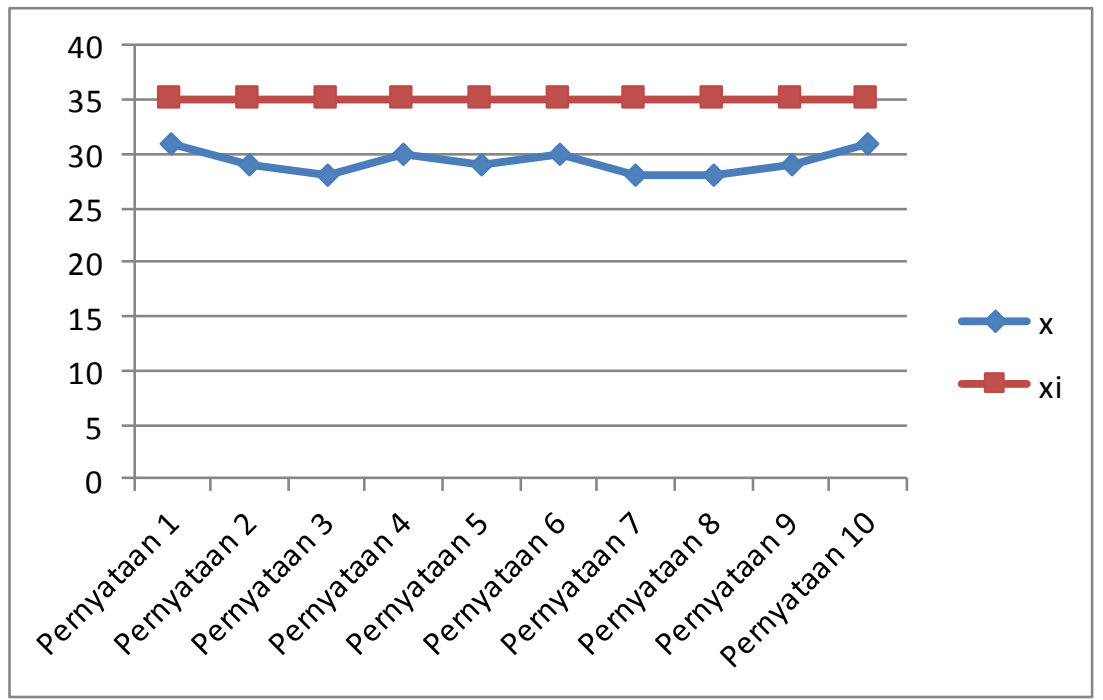

Data diatas dihitung dengan rumus seperti dibawah ini:

$$
\begin{aligned}
P & =\frac{\Sigma X}{\Sigma X i} \times 100 \% \\
P & =\frac{305}{350} \times 100 \% \\
& =87,1 \%
\end{aligned}
$$

Hasil analisis yang didapatkan dari kemenarikan siswa diperoleh prosentase sebesar $87,1 \%$, prosentase ini menunjukkan bahwa siswa tertarik dan lebih semangat dengan penggunaan media roda putar.

Tabel 3.8

\begin{tabular}{|c|c|c|c|c|c|c|c|c|}
\hline \multirow{3}{*}{ 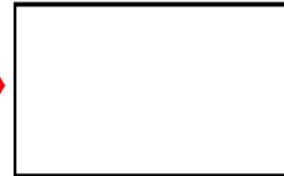 } & \multicolumn{5}{|c|}{ Paired Differences } & \multirow[b]{3}{*}{$t$} & \multirow[b]{3}{*}{ df } & \multirow[b]{3}{*}{ Sig. (2-tailed) } \\
\hline & \multirow[b]{2}{*}{ Mean } & \multirow[b]{2}{*}{ Std. Deviation } & \multirow{2}{*}{$\begin{array}{l}\text { Std. Error } \\
\text { Mean }\end{array}$} & \multicolumn{2}{|c|}{$\begin{array}{l}95 \% \text { Confidence Interval of the } \\
\text { Difference }\end{array}$} & & & \\
\hline & & & & Lower & Upper & & & \\
\hline $\begin{array}{ll}\text { Pair } 1 & \text { PRE TEST - POST TEST }\end{array}$ & $-36,00000$ & 9,23760 & 3,49149 & $-44,54336$ & $-27,45664$ & $-10,311$ & 6 &, 000 \\
\hline
\end{tabular}

Tabel Hasil analisis paired sample t-test

Paired Samples Test

Diketahui nilai $\mathrm{t}_{\text {hitung }}$ adalah -10.311 dengan probalitas ( $\left.\mathrm{sig}\right) 000<0,05$ maka dapat disimpulkan $\mathrm{H}_{\mathrm{a}}$ diterima dan $\mathrm{H}_{\mathrm{o}}$ ditolak. Artinya adanya sebuah pengaruh yang signifikan dari hasil belajar sebelum dan sesudah menggunakan media roda putar materi keragaman suku dan budaya. Media roda putar mampu meningkatkan hasil belajar siswa pada materi keragaman suku dan budaya.

\section{KESIMPULAN}


Nuril Nuzulia, Wlok Khoirul Muna Mabni Zain : Pengembangan Media Putar Pada Mata Pelajaran IPS Berbasis HOTS Keragaman Suku dan Budaya Kelas 4 di MI PSM Padangan Kabupaten Tulungagung

Berdasarkan proses pengembangan dan hasil uji coba media roda putar pada materi keragaman suku dan budaya maka dapat diambil kesimpulan bahwa penelitian dan pengembangan menghasilkan produk yaitu media roda putar materi keragaman suku dan budaya. Media ini dikembanhkan berdasarkan kenyataan yang terjadi di lapangan. Pada MI PSM Padangan belum tersedia media pembelajaran untuk materi keragaman suku dan budaya berbasis HOTS. Perkembangkan media berdasarkan langkah-langkah pengembangan media model Borg and Gall dengan menggunakan uji coba kelayakan yang dilakukan pada ahli isi/materi, ahli desain media, ahli pembelajaran dan siswa kelas IV MI PSM Padangan Ngantru Tulungagung. Materi dan desain media yang dikembangkan sesuai dengan kompetensi dasar.

Hasil uji coba kelayakan media roda putar memiliki kualifikasi valid dan layak menjadi salah satu media berbasis HOTS untuk meningkatkan hasil belajar. Presentase kelayakan yang di dapatkan adalah $86 \%$ dari validasi ahli materi, $86 \%$ validasi ahli desain media, dan $94 \%$ validasi ahli pembelajaran. Presentase kemenarikan media dari siswa MI PSM Padangan Ngantru Tulungagung ini memperoleh presentase $87,1 \%$.

Hasil uji coba penggunaan media roda putar mampu meningkatkan hasil belajar siswa. Hasil penelitian dan pengembangan dibagi menjadi dua yaitu, pre test dan post test. Analisis hasil pre test yang dilakukan oleh tujuh siswa MI PSM Padangan memiliki rata-rata 52,5 sedanglan, untuk hasil post test tujuh siswa tersebut mendapatkan rata-rata 88,5. Langkah selanjutnya yaitu menggunakan analisis uji $\mathrm{t}$ berpasangan (paired sample $t$-test) secara manual dengan hasil $t_{\text {hitung }}$ memiliki nilai 3,897 dan $t_{\text {tabel }}$ dengan nilai 1,943.. Hal tersebut dapat diketahui dari uji t berpasangan bahwa $\mathrm{H}_{\mathrm{o}}$ ditolak dan $\mathrm{H}_{\mathrm{a}}$ diterima karena nilai $t_{\text {hitung }}>t_{\text {tabel }}$. Hasil tersebut menyatakan bahwa media roda putar yang dikembangkan mampu meningkatkan hasil belajar siswa dan melatih kemampuan berpikir siswa.

\section{DAFTAR PUSTAKA}

Arifin, Zaenal. 2014. Penelitian Pendidikan metode dan Paradigma Baru. Bandung: Remaja Rosdakarya.

Arsyad, Azhar. 2002. Media Pembelajaran. Jakarta: PT raja Grafindo Persada.

Daryanto. 2010. Media Pembelajaran. Yogyakarta: Gava Media.

Isnaini, Nurul. 2018. The development of learning media based on roda putar game on mathematic subjects of solid figure material for 5th grade of SDN Purwantoro 4 Malang. Malang: UIN Malang.

Istifarina, Noni. 2016. Penerapan Model Pembelajaran Kooperatif Tipe Teams Games Tournament (Tgt)) Berbantu Media Roda Putar Untuk Meningkatkan Aktifitas Belajar Akuntansi Siswa Kelas Xi Akuntansi 1 SMK Negeri 1 Tempel Tahun Ajaran 2015/2016. Yogyakarta: Universitas Negeri Yogyakarta.

Khairunnisa, Wardah. 2017. Pengembangan media Roda Putar Berbasis Website Untuk Keterampilan Membaca Bahasa Prancis Siswa Kelas XI SMA Angkasa Adisutjipto. Yogyakarta: Universitas Negeri Yogyakarta.

Lindayanti. 2016. Pengaruh model problem based learning berbantukan media roda putar terhadap keterampilan berfikir kritid dan sikap ilmiah siswa kelas XI pada materi sistem gerak SMA Al-Azhar 3 Bandar Lampung. Lampung: Institut Agama Islam Negeri Raden Intan Lampung. 
Nuril Nuzulia, Wlok Khoirul Muna Mabni Zain : Pengembangan Media Putar Pada Mata Pelajaran IPS Berbasis HOTS Keragaman Suku dan Budaya Kelas 4 di MI PSM Padangan Kabupaten Tulungagung

Novianti, Ria. 2008. Pengembangan Permainan Roda Putar Untuk Meningkatkan Kemampuan Berhitung Angka Anak Usia 5-6 Tahun. Jakarta: Educhild Vol. 4 No. 1 Tahun 2015.

Nugroho, Arifin. 2019. Higher Order Thinking Skill. Jakarta: PT Gramedia.

Nurillahi Al Arif, Rizki. 2018. Pengembangan media pembelajaran ular tangga materi keragaman suku dan budaya di Indonesia kelas IV MI Al-Hidayah Kasembon Bululawang Malang. Malang: Uin Malang.

Rinawati. 2015. Meningkatkan Kemampuan Berhitung Melalui Media Roda Putar Pada Anak Kelompok B TK Dharma Wanita Gondang Kecamatan Bandung Kabupaten Tulungagung Tahun Pelajaran 2014/2015. Kediri: Universitas Nusantara PGRI, 2015.

Risnawati. 2008. Strategi Pembelajaran Matematika. Suska Press. 2008.

Sadiman, Arif dkk. 2014. Media Pendidikan. Jakarta: PT rajagrafinda Persada.

Sanaky, Hujair. 2009. Media pembelajaran. Yogyakarta: Safiria Insania Press.

Sanjaya, Wina. 2013. Penelitian Pendidikan Jenis, metode dan prosedur. Jakarta: Kencana Prenada Media Group.

Satrianawati. 2018. Media dan Sumber Belajar. Yogyakarta: CV Budi Utama.

Sudijono, Anas. 2006. Pengantar Evaluasi Pendidikan. Jakarta: PT Raja Grafindo Persada.

Sudjana, Nana. 2013. Penilaian Hasil Proses Belajar Mengajar. Bandung: Remaja Rosdakarya.

Supranto, Johannes. 2016. Statistik Teori \& Aplikasi. Jakarta: PT Gelora Aksara Pratama.

Susanto, Ahmad. 2015. Teori Belajar dan Pembelajaran di Sekolah Dasar. Jakarta: Prenadamedia Group.

Syaodih Sukmadinata, Nana. 2010. Metode Penelitian Pendidikan. Bandung: PT Remaja Rosdakarya.

Undang-Undang Republik Indonesia No. 20. 2003. Sisdiknas. Bandung: Citra Umbara.

Widana, I Wayan. 2017. Penyusunan Soal Higher Order Thinking Skill (HOTS). Jakarta: Direktorat pembinaan SMA Ditjen Pendididikan Dasar dan Menengah 